\title{
Selenoprotein F
}

National Cancer Institute

\section{Source}

National Cancer Institute. Selenoprotein F. NCI Thesaurus. Code C126955.

Selenoprotein $\mathrm{F}$ (162 aa, $\sim 18 \mathrm{kDa}$ ) is encoded by the human SELENOF gene. This protein binds selenium and may play a role in protein folding. 